\title{
Methanol production using hydrogen from concentrated solar energy
}

\author{
Nathalie Monnerie ${ }^{a, *}$, Philipe Gunawan Gan ${ }^{b}$, Martin Roeb ${ }^{a}$, \\ Christian Sattler ${ }^{a}$ \\ a German Aerospace Center (DLR), Linder Hoehe, 51147 Koeln, Germany \\ ${ }^{\mathrm{b}}$ KTH Royal Institute of Technology, Brinnelvagen 68, Stockholm, Sweden
}

\section{H I G H L I G H T S}

- Coupling of methanol production plant with concentrating solar energy is proposed.

- Syngas required for methanol production is produced with thermochemical cycle.

- Flow-sheets and simulations were carried out in MW-range.

- Economic analysis of the process results in methanol production costs of $1.14 € / 1$.

\section{A R T I C L E I N F O}

Article history:

Received 28 October 2019

Received in revised form

19 December 2019

Accepted 29 December 2019

Available online 28 January 2020

Keywords:

Hydrogen

Solar energy

Methanol

Thermochemical redox cycle

Synthesis gas

\begin{abstract}
A B S T R A C T
Concentrated solar thermal technology is considered a very promising renewable energy technology due to its capability of producing heat and electricity and of its straightforward coupling to thermal storage devices. Conventionally, this approach is mostly used for power generation. When coupled with the right conversion process, it can be also used to produce methanol. Indeed methanol is a good alternative fuel for high compression ratio engines. Its high burning velocity and the large expansion occurring during combustion leads to higher efficiency compared to operation with conventional fuels. This study is focused on the system level modeling of methanol production using hydrogen and carbon monoxide produced with cerium oxide solar thermochemical cycle which is expected to be $\mathrm{CO}_{2}$ free. A techno-economic assessment of the overall process is done for the first time. The thermochemical redox cycle is operated in a solar receiver-reactor with concentrated solar heat to produce hydrogen and carbon monoxide as the main constituents of synthesis gas. Afterwards, the synthesis gas is turned into methanol whereas the methanol production process is $\mathrm{CO}_{2}$ free. The production pathway was modeled and simulations were carried out using process simulation software for MW-scale methanol production plant. The methanol production from synthesis gas utilizes plug-flow reactor. Optimum parameters of reactors are calculated. The solar methanol production plant is designed for the location Almeria, Spain. To assess the plant, economic analysis has been carried out. The results of the simulation show that it is possible to produce 27.81 million liter methanol with a $350 \mathrm{MW}_{\text {th }}$ solar tower plant. It is found out that to operate this plant at base case scenario, $880685 \mathrm{~m}^{2}$ of mirror's facets are needed with a solar tower height of $220 \mathrm{~m}$. In this scenario a production cost of $1.14 € / 1$ Methanol is predicted.
\end{abstract}

(c) 2020 Hydrogen Energy Publications LLC. Published by Elsevier Ltd. All rights reserved.

\footnotetext{
* Corresponding author.

E-mail address: nathalie.monnerie@dlr.de (N. Monnerie).
} 


\section{Introduction}

As part of the energy transition, it is important to develop alternative liquid fuels for the transport sector, which can be produced by using renewable energy from non-limited material resources with significantly reduced $\mathrm{CO}_{2}$ emissions compared to state-of-the-art technologies. Indeed, according to relevant studies, despite of all efforts for electric, natural gas and hydrogen mobility in the long term beyond 2040, it is likely that liquid fuels will play an important role [1-3]. It is possible to produce synthesis gas from water and $\mathrm{CO}_{2}$ by using concentrating renewable solar energy in a solar receiverreactor, the synthesis gas being then converted in fuels or chemical product. The solar thermal processes for water and $\mathrm{CO}_{2}$ splitting introduced by Nakamura [4] open up thus a great technical potential to produce renewable fuels from the raw materials mentioned. In this study, a solar reactor using cerium oxide $\left(\mathrm{CeO}_{2}\right)$ and operating at $1773 \mathrm{~K}$ and $1300 \mathrm{~K}$ for reduction and oxidation step respectively under nonstoichiometric condition [5-11] is applied to produce solar hydrogen and carbon monoxide, constituting together synthesis gas. Cerium oxide has the advantages of faster kinetics and better stability and selectivity in comparison to the most researched alternatives like the ferrite-based oxides [12-15]. The synthesis gas thus produced can be then converted into methanol. Methanol is namely a suitable substitute fuel for high compression rate motor [16-18]. Nowadays, methanol is employed as fuel (as substitute as well as blend) in the Chinese provinces [19]. Some studies were already made on methanol production with solar reforming of natural gas [20-22]. Renewable methanol synthesis is also possible using renewable hydrogen produce in a proton exchange membrane electrolyzer driven by renewable geothermal power and captured $\mathrm{CO}_{2}$ from S-Graz cycle $[23,24]$ or using hydrogen from high temperature solid oxide cell [25]. Other studies report on the production of methanol using hydrogen from wind-driven electrolysis and carbon dioxide captured [26,27]. Studies about methanol production with different renewable sources have been made [28-30] but none of them considers the solar thermochemical cycle assumed in this paper.

The objective of this work is to study the potential of coupling concentrated solar energy producing synthesis gas with a methanol synthesis process using it to produce methanol. Every commercialized methanol pathways use namely synthesis gas production before methanol synthesis process [31]. This study focuses on the process modeling and economic evaluation of methanol production plant using hydrogen and carbon monoxide produced in a thermochemical cycle driven by concentrated solar energy. Flow chart and flowsheets are developed and simulated with the simulation tool Aspen Plus ${ }^{\circledR} 10.0$ for a large-scale system and techno-economic analysis is carried out for the first time for the overall production process from solar radiation until methanol as end-product to assess the methanol production plant. The paper is structured as follows: in section "Principle of the methanol production plant using hydrogen produced by concentrated solar energy" the investigated process is defined. In section "Method and assumptions" the applied methodology is introduced as well as the assumptions taken into account. In section "Results and discussion" the results are presented and discussed. Finally in section "Conclusions", the most important outcomes of this study are summarized and an outlook for further works is given.

\section{Principle of the methanol production plant using hydrogen produced by concentrated solar energy}

Solar towers are a large scale technology in which many computer-controlled sun-tracking mirrors, so called heliostats, are used to concentrate the incoming solar radiations onto a solar receiver positioned on the top of a tower. The solar radiation is absorbed by the receiver and turned into heat. This heat can then be utilized in any heat driven process, like for electricity generation or for driving chemical reactions. Thermochemical redox metal oxide cycle taking place in a solar reactor can also be coupled with concentrated solar thermal technology in order to convert solar energy into chemical energy. Combining this cycle with water and/or carbon dioxide enables to produce hydrogen and $\mathrm{CO}$, which compose together synthesis gas and open thus a route to solar fuels production. During the first step of the cycle (the water or $\mathrm{CO}_{2}$ splitting) the reduced material is oxidized by taking oxygen from water or $\mathrm{CO}_{2}$ and producing hydrogen or $\mathrm{CO}$. In the second step the material is reduced again, setting some of its lattice oxygen free. One major advantage is that hydrogen or $\mathrm{CO}$ are produced in different steps as oxygen so that no separation of hydrogen (or CO) and oxygen is needed.

In the process investigated in this study, synthesis gas is produced via solar thermochemical redox cycle and then used to produce methanol. Fig. 1 shows the flowchart of the methanol production plant using hydrogen and carbon monoxide from concentrated solar energy. The solar thermochemical cycle, including oxidation and reduction steps, takes place in the solar reactor placed on the top of the tower, transforming water and $\mathrm{CO}_{2}$ in synthesis gas. Nitrogen is used as sweep gas in the reduction process to carry oxygen with it. The oxygen is then separated from the nitrogen in the air separation unit (ASU) so that this last one can be reused. The synthesis gas produced in then stored in a synthesis gas tank before entering the methanol rector in which methanol is produced. After that methanol is separated from unreacted syngas which is recycled in the methanol reactor. The solar part of the facility operates intermittently while the methanol production from synthesis gas runs uninterrupted. In order to make this possible, synthesis gas storage is implemented between the solar part producing it and the methanol production part using it. Thus the synthesis gas flow going into the methanol reactor can be regulated.

\section{Method and assumptions}

The methanol production plant using hydrogen from concentrated solar energy is modeled and simulated following the scheme depicted in Fig. 2. Modeling of each sub-system is 


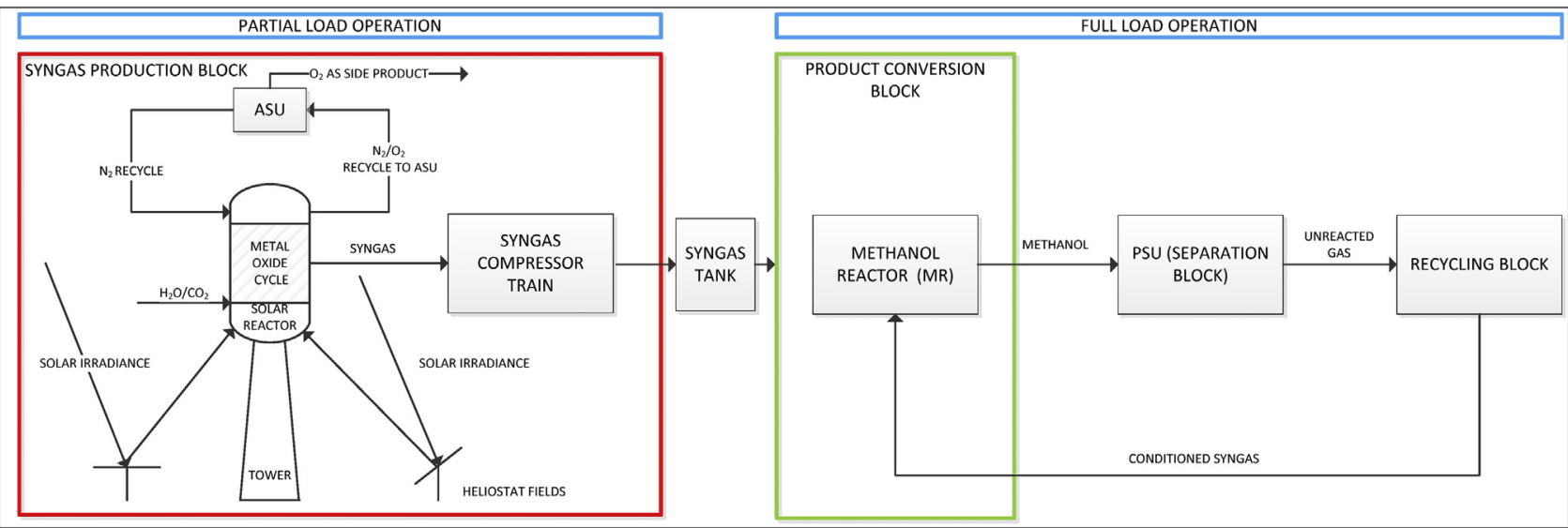

Fig. 1 - Flow chart of the methanol production plant using hydrogen from concentrated solar energy.

done in the same software environment. Several assumptions have been taken into account for the simulation and are detailed in the following sub-chapters.

\section{Layout of the solar field}

The performance of solar energy plants depends on the site where they are built and the corresponding insolation conditions. The concentrated solar thermal technology considered here to deliver the required high temperature consists in a solar tower configuration plant located in Almerìa, Spain, for which the heliostat field is designed using in-house software HFLCAL developed by DLR [32].

The simulation takes into account all relevant loss mechanisms to find the best heliostat field configuration. The different considered loss mechanisms consist in cosine loss,

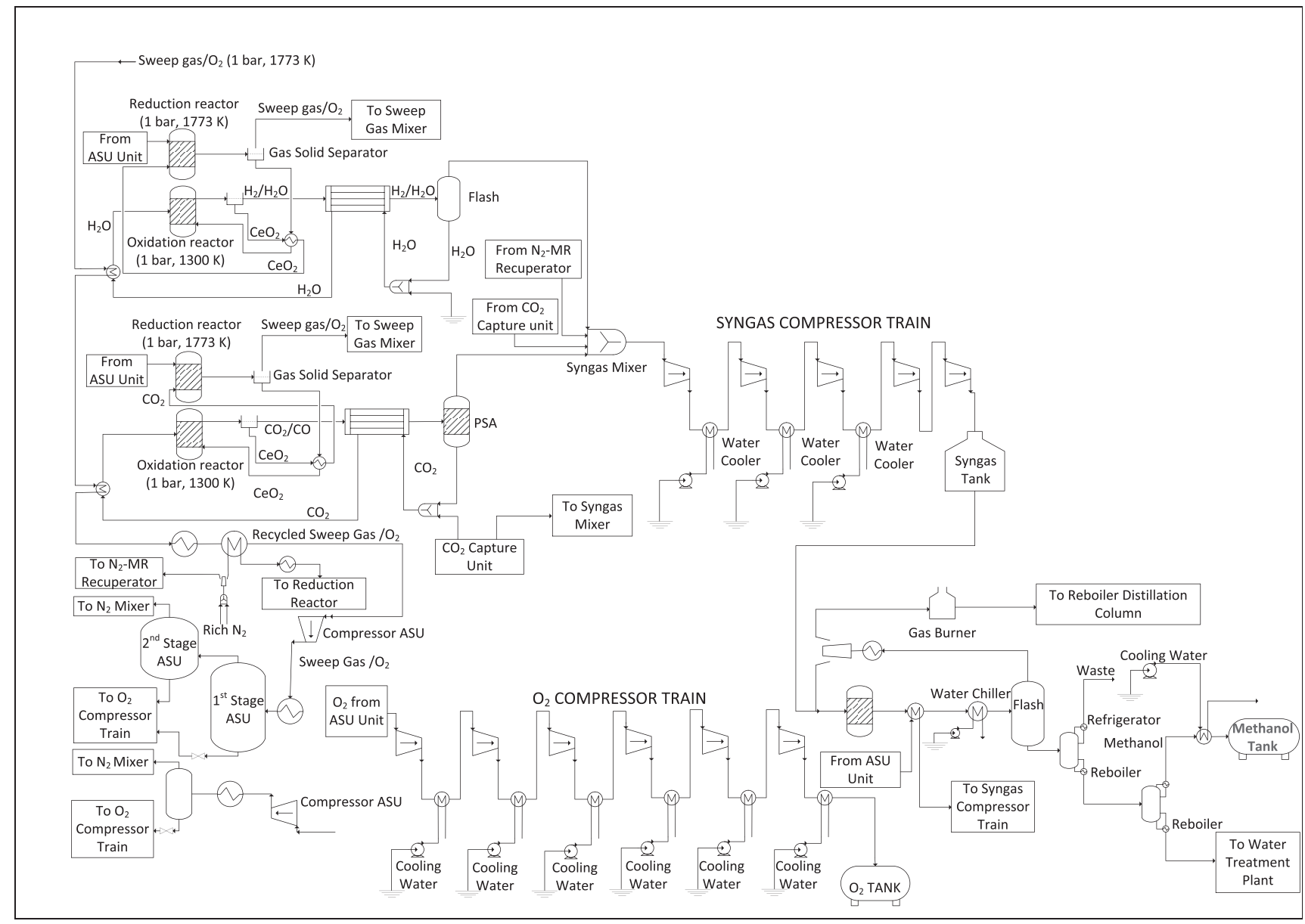

Fig. 2 - Flowsheet of the overall solar methanol production plant. 
shading, reflectivity, blocking, atmospheric attenuation and spillage. A more extensive description of these different losses is provided by the corresponding literature [32-35].

In this study, the considered heliostats are of the type Sanlucar 120 [36], which have a reflective area of $121.34 \mathrm{~m}^{2}$ and a total beam error of 3.3 mrad. The mirror reflectivity is $87 \%$, including cleanliness and availability. The annual efficiency of the solar part $\eta_{\mathrm{s}}$ is defined as the net thermal power $P_{\text {th }}$ that the reactor provides throughout the year (including solar reactor losses) divided by the theoretical maximum of solar radiation (expressed as the direct normal irradiance DNI) hitting the entire mirror surfaces $\left(A_{\text {Mirror }}\right)$ and considers thus the efficiency of the solar reactor and of the solar heliostat field [37]:

$$
\eta_{\mathrm{S}}=\frac{\int_{\mathrm{t}=0}^{\mathrm{TMY}} P_{\mathrm{th}}(\mathrm{t}) \mathrm{dt}}{\mathrm{A}_{\text {Mirror }} \cdot \int_{\mathrm{t}=0}^{\mathrm{TMY}} \mathrm{DNI}(\mathrm{t}) \mathrm{dt}}
$$

As an initial study has shown that the total heliostat field's efficiency is higher in this case study by using multi aperture as by using single aperture, a multi aperture with secondary concentrator receiver is chosen. In this configuration the solar reactor apertures face diverse direction and surround the tower. The heliostats are placed in the area following the direction where the apertures are facing at and the distribution of heat power for each heliostat zone is depicted in Table 1.

\section{Modeling of the solar reactor}

A solar reactor using cerium oxide $\left(\mathrm{CeO}_{2}\right)$ as redox material is used to produce hydrogen and carbon monoxide [39]. $\mathrm{CeO}_{2}$ is thermally reduced efficiently at a temperature of $1773 \mathrm{~K}$. The reduced $\mathrm{CeO}_{2-\delta \text { ox }}$ is then oxidized in the presence of $\mathrm{H}_{2} \mathrm{O}$ or $\mathrm{CO}_{2}$ so that $\mathrm{H}_{2}$ or $\mathrm{CO}$ is respectively generated at a temperature below $1300 \mathrm{~K}$. The following formula govern the partial redox of cerium oxide [40]:

$$
\begin{aligned}
& \mathrm{CeO}_{2-\delta \text { ox }} \rightarrow \mathrm{CeO}_{2-\delta \text { red }}+\Delta \delta / 2 \mathrm{O}_{2} \\
& \mathrm{CeO}_{2-\delta \text { red }}+\Delta \delta \mathrm{H}_{2} \mathrm{O} \rightarrow \mathrm{CeO}_{2-\delta \text { ox }}+\Delta \delta \mathrm{H}_{2} \\
& \mathrm{CeO}_{2-\delta \text { red }}+\Delta \delta \mathrm{CO}_{2} \rightarrow \mathrm{CeO}_{2-\delta \text { ox }}+\Delta \delta \mathrm{CO}
\end{aligned}
$$

where $\Delta \delta$ represents the difference between reduction and oxidation amount. To model the non-stoichiometric

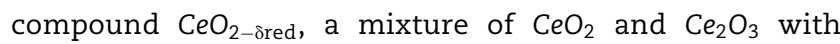
certain mole ratio is used. The ratio is supposed to follow $\delta_{\text {red }}$ according to equations (5) and (6) which follows the conservation of mass law. $\mathrm{z}_{\mathrm{CeO}_{2}}$ and $\mathrm{z}_{\mathrm{Ce}_{2} \mathrm{O}_{3}}$ are the mole fractions of cerium (IV) oxide and cerium (III) oxide

Table 1 - Power fraction among subfield in multi aperture arrangement [38].

\begin{tabular}{lcccc} 
Latitude & \multicolumn{4}{c}{ Power fraction } \\
\cline { 2 - 5 } & $\mathrm{N}$ & $\mathrm{NE} / \mathrm{NW}$ & $\mathrm{SE} / \mathrm{SW}$ & $\mathrm{S}$ \\
\hline $20^{\circ} \mathrm{N}$ & 21 & 18 & 15 & 13 \\
$40^{\circ} \mathrm{N}$ & 22 & 19 & 14 & 12 \\
\hline
\end{tabular}

respectively inside the non-stoichiometric reduced metal oxide [40].

$$
\begin{aligned}
& \mathrm{z}_{\mathrm{CeO}_{2}}=\frac{1-2 \delta_{\text {red }}}{1-\delta_{\text {red }}} \\
& \mathrm{z}_{\mathrm{CeO}_{2}}+\mathrm{z}_{\mathrm{Ce}_{2} \mathrm{O}_{3}}=1
\end{aligned}
$$

By using these equations the ratio of $\mathrm{Ce}$ to $\mathrm{O}$ atoms for the $\mathrm{CeO}_{2} / \mathrm{Ce}_{2} \mathrm{O}_{3}$ mixture will be the same as for $\mathrm{CeO}_{2-\delta}$. To model the solar reactor with Aspen Plus ${ }^{\circledR}$ a yield reactor module (RYield) based on mass balance, governed by redox extent and reactor's conversion is applied. A condensation at $298 \mathrm{~K}$ is carried out to extract water from the hydrogen stream and the flashing unit is used to separate hydrogen from water. Temperature of $298 \mathrm{~K}$ is chosen to minimize the heat needed to raise the temperature of fresh water before coming into oxidation step. To separate carbon dioxide from carbon monoxide stream Pressure Swing Adsorption (PSA) running at 1 bar and $298 \mathrm{~K}$ is used (see Fig. 2).

The general assumptions for the modeling process are summed up in Table 2 [40].

\section{Modeling of the methanol reactor}

The hydrogen and carbon monoxide generated is then stored in the synthesis gas storage before to be sent to the methanol reactor to produce methanol. To model the methanol an adiabatic plug-flow reactor utilizing R-Plug module within Aspen Plus ${ }^{\circledR}$ under $\mathrm{Cu}$ based catalyst $[31,41]$ is applied. The employment of adiabatic working mode is due to its simplicity and robustness [42] while governing chemical kinetic reactions are discussed by Bussche et al. [41]. LHHW kinetic type is applied to bring the reaction into R-Plug simulation environment within Aspen Plus ${ }^{\circledR}$. Conforming to Bussche et al. [41], the limitations of the reaction kinetic are $15-51$ bar for the pressure, $180-280{ }^{\circ} \mathrm{C}$ for the temperature and $\mathrm{H}_{2} / \mathrm{CO}$ of $0-4.1$. The reaction constant values are given in Table 3.

The equilibrium constants based on partial pressure $K_{p}$ is taken from Graaf et al. [43] and can be seen from equations (7)

\begin{tabular}{|c|c|}
\hline Max Thermal Power to Solar Reactor & $350 \mathrm{MW}_{\text {th }}$ \\
\hline Metal oxide & Ceria $\mathrm{CeO}_{2}$ \\
\hline Reduction temperature & $1773 \mathrm{~K}$ \\
\hline Oxidation temperature & $1300 \mathrm{~K}$ \\
\hline Pump efficiency & 0.8 isentropic \\
\hline Compressor efficiency & 0.9 mechanical efficiency \\
\hline Pinch Point Over Heat Exchanger & $5 \mathrm{~K}$ \\
\hline Cooling Water Temperature & $293 \mathrm{~K}$ \\
\hline Location & Almeria $\left(37^{\circ} 05^{\prime} \mathrm{N}, 2^{\circ} 21^{\prime} \mathrm{W}\right)$ \\
\hline
\end{tabular}
and (8):

$\log \mathrm{K}_{\mathrm{p} \mathrm{MeOH}}=3066 / \mathrm{T}-10.592\left(\mathrm{bar}^{-2}\right)$

$\log \mathrm{K}_{\mathrm{p} \text { RWGS }}=-2073 / \mathrm{T}+2.029\left(\mathrm{~Pa}^{-1}\right)$ 
Table 3 - Reaction constant values for methanol synthesis [41].

\begin{tabular}{llll} 
Variable & \multicolumn{1}{c}{ Metric } & \multicolumn{1}{c}{$\mathrm{A}_{\mathrm{i}}$} & \multicolumn{1}{c}{$\mathrm{B}_{\mathrm{i}}$} \\
\hline$k_{\mathrm{MeOH}}$ & mol kg $_{\text {cat }}^{-1} \mathrm{~s}^{-1} \mathrm{bar}^{-2}$ & 1.07 & 36696 \\
$k_{\text {RWGS }}$ & mol kg $_{\text {cat }}^{-1} \mathrm{~s}^{-1} \mathrm{bar}^{-1}$ & $1.22 \cdot 10^{10}$ & -94765 \\
$\mathrm{~K}_{a}$ & - & 3453.38 & - \\
$\mathrm{K}_{b}$ & bar $^{-0.5}$ & 0.499 & 17197 \\
$\mathrm{~K}_{\mathrm{c}}$ & bar $^{-1}$ & $6.62 \cdot 10^{-11}$ & 124119
\end{tabular}

The reactor is supposed to work using catalyst with exact cylindrical configuration. The catalyst has a density of $1190 \mathrm{~kg} / \mathrm{m}^{3}$ and the vacant fraction of the bed is 0.285 [44]. Recycling of unreacted synthesis gas back into the methanol reactor is considered in order to optimize the methanol production. Unreacted synthesis gas is separated using flash at $298 \mathrm{~K}$. The product separation unit is simulated using RadFrac module. Before entering the first distillation column, the mixture coming from the methanol reactor is flashed. In the first stage of distillation column the unreacted gas is separated from alcohol mixtures. The bottom stream is next sent directly to the second stage distillation unit for last extraction of methanol. The layout of each stage distillation column is given in Table 4.

Flow chart is defined for the coupling of the methanol production plant with the concentrated solar energy source. This flow chart is simulated with Aspen Plus ${ }^{\circledR}$ and presented in Fig. 2.

\section{Economic evaluation}

Economic analysis is carried out to assess the methanol production plant using hydrogen from concentrated solar energy. Total capital investment (TCI) was calculated including contingency and auxiliary facilities. The cost estimation is based on results of the simulation. The operation and maintenance costs O\&M reflect fixed and variable costs per year, added for the whole period of consideration. The general assumptions of the economic evaluation of the plant are listed in Table 5.

To calculate the methanol production costs (MPC), the annuity method is used [45]. An interest rate $\left(i_{r}\right)$ of $6 \%$ [45] and a lifetime of plant $\left(\mathrm{n}_{\text {lifetime }}\right)$ of 25 years are assumed. The present value (PV) is defined using the calculated costs. The multiplication of this present value with the annuity factor (AF) determines an annual basis, which, divided by the annual

Table 4 - Base case distillation column configuration for methanol reactor system.

\begin{tabular}{cccc} 
& $\begin{array}{c}\text { Number } \\
\text { of stages }\end{array}$ & $\begin{array}{c}\text { Distillate to } \\
\text { Feed Ratio for } \\
\text { Distillation } \\
\text { Column }\end{array}$ & Reflux ratio \\
\hline $\begin{array}{c}\text { 1st } \\
\text { stage } \\
\begin{array}{c}\text { distillation } \\
\text { 2nd }\end{array}\end{array}$ & 5 & 0.022 & 1.28713 \\
\hline
\end{tabular}

Table 5 - General economic assumptions.

\begin{tabular}{ll} 
Interest rate & $6 \%[45]$ \\
Life time of plants $\left(n_{\text {lifetime }}\right)$ & 25 years \\
USD to $€$ conversion rate & $0.8[46]$ \\
$\mathrm{CeO}_{2}$ price 2018 & $5.6 € / \mathrm{kg}[47]$ \\
Copper cost for methanol reactor & $0.56688 € / \mathrm{kg}[47]$ \\
Heliostat cost $/ \mathrm{m}^{2}$ & $103 \mathrm{USD}_{2015}$ \\
Land price & $800000 € / \mathrm{km}^{2}[48]$ \\
\hline
\end{tabular}

amount of produced fuel $\left(\mathrm{V}_{\text {fuel }}\right)$, gives the methanol production costs (see equations (9)-(11)) [45]:

$\mathrm{PV}=\mathrm{TCI}+\sum_{n=1}^{n_{\text {lifetime }}} \frac{\left(\mathrm{O \&} \mathrm{M}_{n}\right)-\mathrm{R}_{n}}{\left(1+i_{r}\right)^{n}}$

with $R_{n}$ plant side income from side product (if any) at year $n$.

$A F=\left(1+i_{r}\right)^{n} \cdot \frac{i_{r}}{\left(1+i_{r}\right)^{n}-1}$

MPC $[€$ pro L $]=\frac{\text { PV.AF }}{\text { Vfuel }}$

Data for mechanical and chemical equipment is taken from Ulrich et al. [49]. Heliostat costs are assumed with 103 $\mathrm{USD} / \mathrm{m}^{2}$ [48]. The investment cost for the solar tower is assumed to be $20 €_{2015} / \mathrm{kWth}$ [50] and the costs for the solar reactor are taken to be $17.8 €_{2015}$ per $\mathrm{kWh}$ [50]. For the carbon dioxide required in the solar thermochemical cycle, cost of 100 $€_{2015} /$ ton of yearly captured carbon dioxide is assumed [50]. To update the cost to 2018, CEPCI method is used where the updated cost is the ratio of CEPCI at 2018 to CEPCI at reference year multiplied by the price at reference year [49]. Ulrich et al. is based on 2004 price where $\mathrm{CEPCI}_{2004}$ is 400 while $\mathrm{CEPCI}_{2018}$ is $567.5[51]$

\section{Results and discussion}

\section{Results for heliostat field}

The heliostat field was calculated for the location Almeria, Spain. The result of the simulation is depicted on Fig. 3.

The thermal efficiency of the multi aperture arrangement with secondary concentrator is considered to be 0.85 and the reflectivity of the secondary concentrator is assumed to be 0.9 [52]. The total heliostat field efficiency is calculated to be $52.1 \%$. This efficiency value corresponds indeed to the average heliostat field efficiency for such a plant size for this location [53]. The results of the simulation show that 7258 heliostats with a total mirror's facets surface of $880685 \mathrm{~m}^{2}$ are needed to operate a 350 MWth plant with a solar reactor thermal efficiency of $85 \%$. The tower height has an optimized size of $220 \mathrm{~m}$. The land radius is $1805 \mathrm{~m}$. The results are presented in Table 6.

\section{Results for solar reactor}

By the modeling of the solar reactor, the hydrogen and carbon monoxide productions have been separately simulated and 

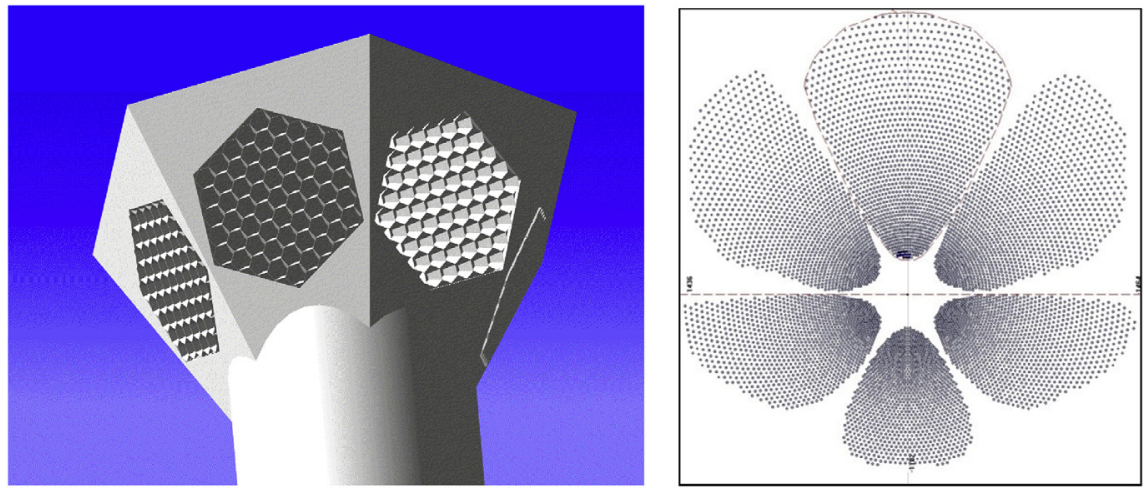

Fig. 3 - Multi aperture reactor arrangement [38] - Heliostat field arrangement for solar methanol production plant located in Almeria, Spain.

\section{Table 6 - Results of the heliostat field's design.}

Annual average receiver-reactor power $\left[\mathrm{MW}_{\mathrm{th}}\right]$

Total mirror's facets surface $\left[\mathrm{m}^{2}\right]$

880685

Annual average solar efficiency [\%]

the reduction and oxidation chamber have been modeled for each. A non-stoichiometric reduction and oxidation operation has been implemented in the model using R-Yield module from Aspen Plus ${ }^{\circledR}$. The simplified corresponding flow chart is depicted in Fig. 4.

The separation of the solid and gas mixture is modeled using cyclone separator module, thus for both reduction and oxidation product stream. The separation of hydrogen from remained steam which has not been split is simulated in a condensation step at $298 \mathrm{~K}$ following of a flashing unit. Afterwards the flashed water is combined with a stream of fresh make-up water and recycled back to the oxidation chamber. For the separation of carbon monoxide, a Pressure Swing Adsorption (PSA) system is considered, running at ambient condition of $298 \mathrm{~K}$ and under atmospheric pressure. This PSA unit is modeled as a black-box separation module by setting the carbon monoxide fraction to be 1 for the carbon monoxide outlet stream.

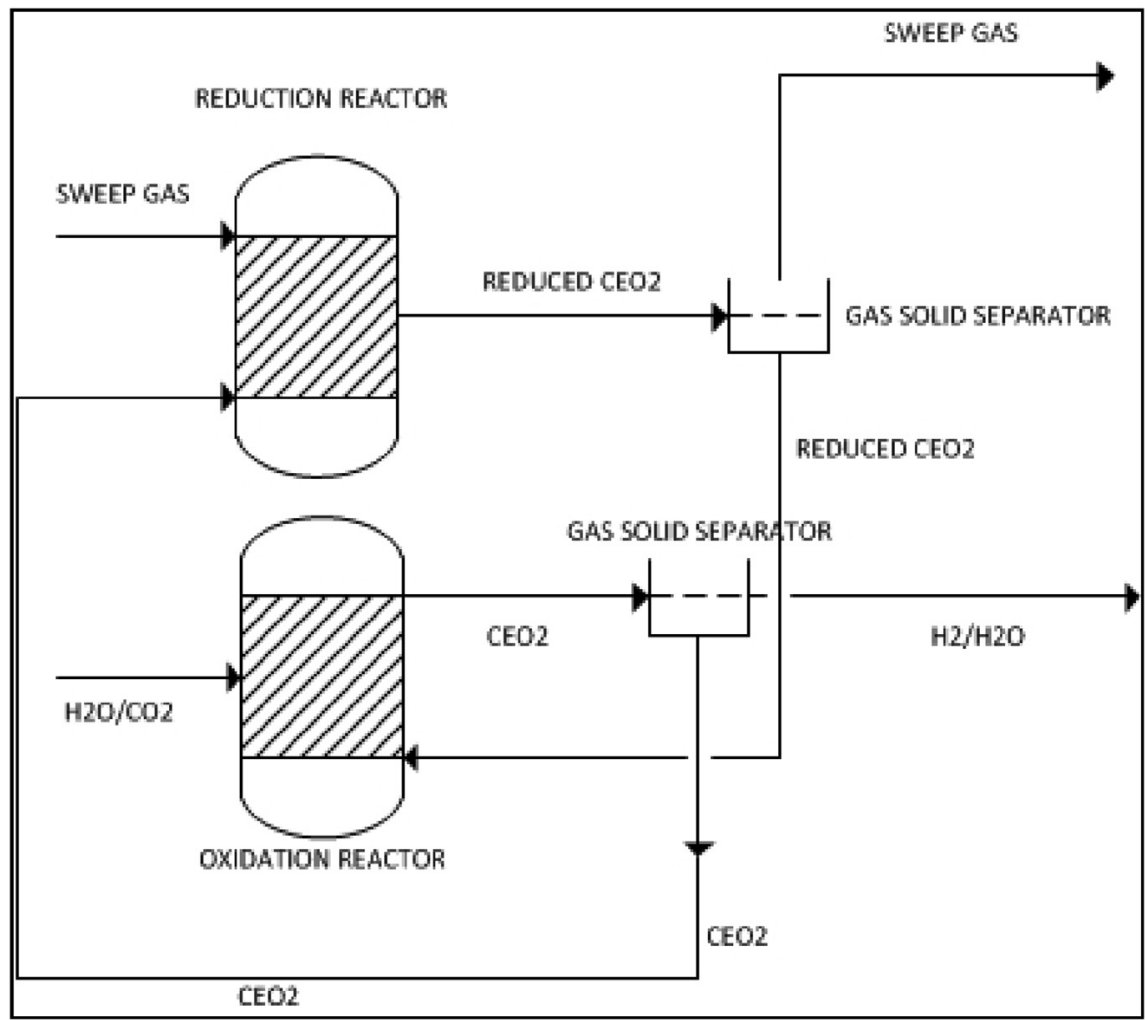

Fig. 4 - Simplified solar reactor chart. 


\section{Results for methanol reactor}

The methanol reactor model was validated by comparing its concentration profiles with the results obtained in Bussche et al. [41]. The reactor was assumed to be a single tube adiabatic reactor. The operation conditions are presented in Table 7.

The optimum parameters of this reactor have been calculated. By the optimization, the pressure stays uniform at 50 bar in the reactor, which corresponds to the limit of validity of kinetic equation and to the maximal methanol output according to Bussche et al. [41]. The mole ratio of carbon monoxide to carbon dioxide is constant at $4 / 3$, corresponding also to the value advanced by Bussche et al. [41]. The optimum value of the ratio hydrogen to carbon monoxide is thus found to be 3.588 and the reactor's diameter $1.5 \mathrm{~m}$.

The main results for the process simulation of the methanol plant production using hydrogen from concentrated solar energy including the heliostat field layout are presented in Table 8.

With sufficient synthesis gas storage it is possible to produce 27.81 million liter of methanol per year.

\section{Results for economic analysis}

The total capital investment of the solar driven methanol production plant is calculated to be 254 Million Euro. The share of investment for each part of the plant is shown on Fig. 5. Around one third (36\%) of the total capital investment come from the concentrated solar thermal components which represent thus the biggest contributors towards the total capital investment. $80 \%$ of the solar components investment costs come from the heliostat field. The equipment costs, consisting in compressors, pumps, mixers, tanks, methanol reactor, product separation unit, water desalination unit, oxygen separation, synthesis gas buffer tank etc., represent the second biggest contributor towards the total capital investment plant.

The operation and maintenance costs of the solar tower system are assumed to be $2 \%$ [48] of the total cost of CSP

Table 7 - Operation conditions to validate methanol reactor according to Refs. $[41,44]$.

\begin{tabular}{ll} 
Reactor & \\
Diameter (m) & 0.016 \\
Length (m) & 0.15 \\
Operating conditions & \\
Temperature (K) & 493,2 \\
Pressure (bar) & 50 \\
Mass Flow of Input Gas (kg/s) & $2.8 \cdot 10-5$ \\
Feed Composition & \\
$\mathrm{CO}(\mathrm{mol} \%)$ & 4.00 \\
$\mathrm{H}_{2} \mathrm{O}(\mathrm{mol} \%)$ & 0.00 \\
$\mathrm{Methanol}(\mathrm{mol} \%)$ & 0.00 \\
$\mathrm{H}_{2}$ (mol\%) & 82.0 \\
$\mathrm{CO}$ (mol\%) & 3.00 \\
Inert gas $\mathrm{N}_{2}\left(\mathrm{~mol}^{2}\right)$ & 11.0 \\
Catalyst & \\
Density (kg/m $\left.{ }^{3}\right)$ & 1190 \\
Bed Void Fraction & 0.285 \\
\hline
\end{tabular}

Table 8 - Main results of the process simulation.

\begin{tabular}{ll} 
Location & Almerìa, Spain \\
Number of heliostats & 7258 \\
Tower height $[\mathrm{m}]$ & 220 \\
Heliostat field efficiency & $52.1 \%$ \\
Methanol reactor pressure [bar] & 50 \\
{$\left[\mathrm{H}_{2} / \mathrm{CO}\right]$ for methanol reactor } & 3.588 \\
Methanol reactor diameter $[\mathrm{m}]$ & 1.5 \\
Methanol reactor equilibrium temperature $[\mathrm{K}]$ & 493.2 \\
Methanol output [Million liter/year] & 27.81 \\
\hline
\end{tabular}

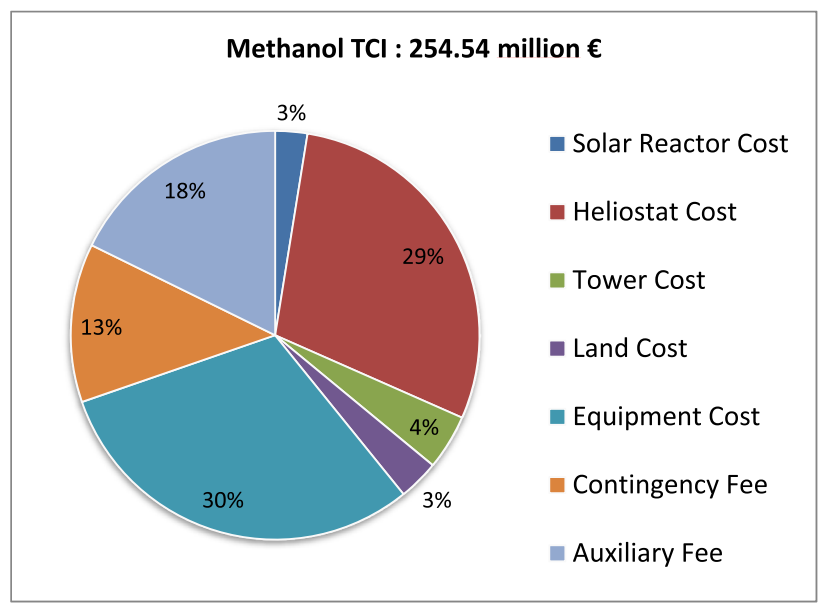

Fig. 5 - Total capital investment for the solar methanol production plant.

system which comprises the tower, heliostats, land and solar reactor costs. Moreover it is assumed for the solar reactor that the redox material $\mathrm{CeO}_{2}$ inside the reactors must be replaced once a year. Methanol reactor's operation and maintenance cost are based on reactor's volume and catalyst density while fresh catalyst is fed once every two years [31]. Based on the results, heliostat cost reduction would be beneficial for developing such system.

A production cost of $1.14 € / \mathrm{L}$ methanol is obtained for an annual methanol production of 27.81 million liter. Comparing to the market price of methanol in Europe [54], the production cost obtained here from the simulation is almost 4 times bigger than the market price. Further efforts in this technology are needed in order to make this solar methanol production pathway competitive for the market.

\section{Conclusions}

Methanol production from solar synthesis gas produced by a thermochemical cycle using cerium oxide has been simulated and analyzed. A flowsheet of the overall process has been developed and simulated with the simulation tool Aspen Plus ${ }^{\circledR}$. The solar reactor and the methanol reactor have been modeled with this software, too. The overall plant from heliostat field to methanol production reactor has been simulated for the first time for the location Almeria, Spain. The 
results show that an annual production of 27.81 million liter methanol with sufficient synthesis gas storage is feasible. For this a multi aperture solar field has been designed using HFLCAL and showed that $880685 \mathrm{~m}^{2}$ of heliostat are needed with an optimized tower height of $220 \mathrm{~m}$. The methanol reactor was modeled with a plug-flow reactor with respective kinetic of reactions. Optimum operation temperature, diameter and pressure of this reactor have been calculated. Finally a techno-economic study of the investigated process has been carried out and methanol production costs of $1.14 € / 1$ have been calculated. The concentrated solar thermal components are the main contributor to the total capital investment. Therefore it seems obvious that a reduction of the concentrated solar thermal components costs, especially the heliostats costs will yield better economic viability of the plant. Moreover, other locations with higher DNI will definitely improve the results and decrease the methanol production costs. As a next step, a life cycle analysis should be carried out to underline the environmental advantages of developing such plant.

\section{Acknowledgments}

The authors of this paper gratefully acknowledge the funding of the project SolareKraftstoffe (Grant agreement Nr. 03EIV221) by the Federal Ministry for Economic Affairs and Energy, on the basis of a decision by the German Bundestag.

\section{Abbreviations}

$\begin{array}{ll}\text { AF } & \text { Annuity Factor } \\ \text { ASU } & \text { Air Separation Unit } \\ \text { CEPCI } & \text { Chemical Engineering Plant Cost Index } \\ \text { CSP } & \text { Concentrated Solar Power } \\ \text { DNI } & \text { Direct Normal Irradiance } \\ \text { LHHW } & \text { Langmuir-Hinshelwood-Hougen-Watson } \\ \text { MPC } & \text { Methanol Production Costs } \\ \text { MR } & \text { Methanol Reactor } \\ \text { N } & \text { North } \\ \text { NE } & \text { North-East } \\ \text { NW } & \text { North-West } \\ \text { O\&M } & \text { Operation and Maintenance costs } \\ \text { PSA } & \text { Pressure Swing Adsorption } \\ \text { PSU } & \text { Product Separation Unit } \\ \text { PV } & \text { Present Value } \\ \text { S } & \text { South } \\ \text { SE } & \text { South-East } \\ \text { SW } & \text { South-West } \\ \text { SYNGAS Synthesis Gas } \\ \text { TCI } & \text { Total Capital Investment } \\ \text { USD } & \text { US dollar }\end{array}$

\section{R E F E R E N C E S}

[1] Willner T, Lucka K, Gunther A. Fortschrittliche alternative flüssige Brenn- und Kraftstoffe: Für Klimaschutz im globalen Rohstoffwandel. In: ProcessNet-Arbeitsausschuss
"Alternative flüssige und gasförmige Kraft- und Brennstoffe". DECHEMA e.V; 2017.

[2] Linzenich A, et al. What fuels the adoption of alternative fuels? Examining preferences of German car drivers for fuel innovations 2019;249:222-36.

[3] Hänggi S, et al. A review of synthetic fuels for passenger vehicles. Energy Rep 2019:555-69.

[4] Nakamura T. Hydrogen production from water utilizing solar heat at high temperatures. Sol Energy 1977;19(5):467-75.

[5] de la Calle A, Bayon A. Annual performance of a thermochemical solar syngas production plant based on non-stoichiometric CeO2. Int J Hydrogen Energy 2019;44(3):1409-24.

[6] Zoller S, et al. Heat transfer model of a $50 \mathrm{~kW}$ solar receiver-reactor for thermochemical redox cycling using cerium dioxide. J Sol Energy Eng 2019;141(2):021014.

[7] Bulfin B, et al. Solar thermochemical hydrogen production using ceria zirconia solid solutions: efficiency analysis. Int Hydrogen Energy 2016;41(42):19320-8.

[8] Krenzke PT, Davidson JH. On the efficiency of solar H-2 and $\mathrm{CO}$ production via the thermochemical cerium oxide redox cycle: the option of inert-swept reduction. Energy Fuel 2015;29(2):1045-54.

[9] Bulfin B, et al. Analytical model of $\mathrm{CeO} 2$ oxidation and reduction. J Phys Chem C 2013;117(46):24129-37.

[10] Bhosale RR, et al. A decade of ceria based solar thermochemical H2O/CO2 splitting cycle. Int J Hydrogen Energy 2019;44(1):34-60.

[11] Agrafiotis C, Roeb M, Sattler C. 4.18 solar fuels A2 - dincer, ibrahim, in Comprehensive energy Systems. Oxford: Elsevier; 2018. p. 733-61.

[12] Romero M, Steinfeld A. Concentrating solar thermal power and thermochemical fuels. Energy Environ Sci 2012;5(11):9234.

[13] Chueh WC, Haile SM. Ceria as a Thermochemical reaction medium for selectively generating syngas or methane from $\mathrm{H}_{2} \mathrm{O}$ and $\mathrm{CO}_{2}$. ChemSusChem 2009;2(8):735-9.

[14] Chueh WC, Haile SM. A thermochemical study of ceria: exploiting an old material for new modes of energy conversion and $\mathrm{CO}_{2}$ mitigation. Philos Trans R Soc A Math Phys Eng Sci 2010;368(1923):3269-94.

[15] Abanades S, et al. Investigation of reactive cerium-based oxides for $\mathrm{H}_{2}$ production by thermochemical two-step watersplitting. J Mater Sci 2010;45(15):4163-73.

[16] Methanol economy. Danish Methanol Association; 2011.

[17] Amine M, Barakat Y. Properties of gasoline-ethanolmethanol ternary fuel blend compared with ethanolgasoline and methanol-gasoline fuel blends. Egypt J Pet 2019;28:371-6.

[18] Awad OI, et al. Alcohol and ether as alternative fuels in spark ignition engine: a review. Renew Sustain Energy 2018;82:2586-605.

[19] Maus W, et al. Synthetische Kraftstoffe - OME1: Ein potenziell nachhaltig hergestellter dieselkraftstoff. In 35. Internat. Wiener motorensymposium. Fortschritt-Berichte VDI Reihe 2014;12.

[20] von Storch $\mathrm{H}$, et al. On the assessment of renewable industrial processes: case study for solar co-production of methanol and power. Appl Energy 2016;183:121-32.

[21] Storch Hv, et al. Theoretical and experimental investigation of effective solar mixed reforming for a less carbon intensive production of methanol. In: AIChE annual meeting; 2018. Pittsburgh, USA.

[22] Storch Hv, et al. On the economics of solar chemical processes - case study for solar co-production of methanol and power. In: Solar world congress 2017. Abu Dhabi: UAE; 2017.

[23] Nami H, Ranjbar F, Yari M. Methanol synthesis from renewable $\mathrm{H}_{2}$ and captured $\mathrm{CO}_{2}$ from S-Graz cycle - energy, 
exergy, exergoeconomic and exergoenvironmental (4E) analysis. Int J Hydrogen Energy 2019;44(48):26128-47.

[24] Nami H, Ranjbar F, Yari M. Thermodynamic assessment of zero-emission power, hydrogen and methanol production using captured $\mathrm{CO}_{2}$ from S-Graz oxy-fuel cycle and renewable hydrogen. Energy Convers Manag 2018;161:53-65.

[25] Lonis F, Tola V, Cau G. Renewable methanol production and use through reversible solid oxide cells and recycled $\mathrm{CO}_{2}$ hydrogenation. Fuel 2019;264:500-15.

[26] Matzen M, Demirel Y. Methanol and dimethyl ether from renewable hydrogen and carbon dioxide: alternative fuels production and life-cycle assessment. J Clean Prod 2016;139:1068-77.

[27] Soltanieh M, Azar KM, Saber M. Development of a zero emission integrated system for co-production of electricity and methanol through renewable hydrogen and $\mathrm{CO} 2$ capture. Int J Greenh Gas Control 2012;7:145-52.

[28] Rivarolo M, et al. Feasibility study of methanol production from different renewable sources and thermo-economic analysis. Int J Hydrogen Energy 2016;41(4):2105-16.

[29] Bellotti D, et al. RSM approach for stochastic sensitivity analysis of the economic sustainability of a methanol production plant using renewable energy sources. J Clean Prod 2019;240:117947.

[30] Crivellari A, Cozzani V, Dincer I. Design and energy analyses of alternative methanol production processes driven by hybrid renewable power at the offshore Thebaud platform. Energy Convers Manag 2019;187:148-66.

[31] Lücking L. Methanol production from syngas : process modelling and design utilising biomass gasification and intergrating hydrogen supply. Delft University of Technology Department of Sustainable Energy Technology; 2017.

[32] Schwarzbözl P, Pitz-Paal R, Schmitz M. Visual HFLCAL-A software tool for layout and optimisation of heliostat fields. in SolarPACES 2009. 2009. Berlin, Germany.

[33] Vogel W, Kalb H. Large-scale solar thermal power: technologies, Costs and Development. Wiley; 2010.

[34] Stieglitz R, Heinzel V. Thermische solarenergie Elektronische ressource grundlagen, technologie, Anwendungen, in SpringerLink : Bücher. Berlin, Heidelberg: Springer; 2012. Online-Ressource (XV, 703 S. 461 Abb, digital).

[35] Pitz-Paal R, et al. Solar thermal power production, in transition to renewable energy systems. Wiley-VCH Verlag GmbH \& Co. KGaA; 2013. p. 307-38.

[36] Mancini TR, editor. SolarPaces, Catalog of Solar Heliostats; 2000. Cologne.

[37] Monnerie N, et al. Hydrogen production by coupling pressurized high temperature electrolyser with solar tower technology. Int J Hydrogen Energy 2017;42:13498-509.
[38] Schmitz M, et al. Assessment of the potential improvement due to multiple apertures in central receiver systems with secondary concentrators. Sol Energy 2006;80(1):111-20.

[39] Bulfin B, et al. Thermodynamics of $\mathrm{CeO} 2$ thermochemical fuel production. Energy Fuel 2015;29(2):1001-9.

[40] Gan PG, et al. Modeling, Simulation and Economic Analysis of CSPDriven Solar Fuel Plant for Diesel and Gasoline Production in SolarPaces. Casablanca, Morocco: AIP; 2018.

[41] Bussche KV, Froment G. A steady state kinetic Model fo methanol Synthesis and water gas shift Reaction on Commerical $\mathrm{Cu} / \mathrm{ZnO} / \mathrm{Al}_{2} \mathrm{O}_{3}$ catalyst. Catalyst 1996;161:1-10.

[42] [cited 2018 23.03], https://www.theverge.com/2018/1/8/ 16861914/hyundai-nexo-hydrogen-fuel-cell-ev-car-ces-2018.

[43] Graaf GH, et al. Chemical Equilibria in methanol synthesis chemical engineering science 1986;41:2883.

[44] Chen L, et al. Optimization of methanol yield from a Lurgi reactor. Chem Eng Technol 2011;34:817.

[45] Graf D, et al. Economic comparison of solar hydrogen generation by means of thermochemical cycles and electrolysis. Int J Hydrogen Energy 2008;33(17):4511-9.

[46] Bloomberg. USD to euro. CUR. 201816 April 2018]; Available from: https://www.bloomberg.com/quote/USDEUR:CUR, https://www.bloomberg.com/quote/USDEUR; 2018.

[47] Rare metals. Available from: http://mineralprices.com/; 2018 26 April 2018.

[48] Dieckmann S, et al. LCOE reduction potential of parabolic trough and solar tower CSP technology unitl 2025. Santiago: American Institute of Physics; 2017.

[49] Ulrich GD, Vasudevan PT. Chemical engineering process Design and economics: a practical Guide. Durham, New Hampshire, USA: Process Publishing; 2004.

[50] Falter C. Efficiency potential of solar thermochemical reactor Concepts with ecological and economic performance analysis of solar fuel production. RWTH Aachen; 2017.

[51] Jenkins S. CEPCI updates: January 2018 (prelim.) and December 2017 (final). 2018.

[52] DLR. Internal report - Commercial scale up plant design. Cologne: DLR; 2009.

[53] Schmitz M. Systematischer Vergleich von solarthermischen Turmreflektor- und Turmreceiversystemen. In: Faculty of mechanical Engineering. RWTH Aachen; 2006.

[54] Methanex posts regional contract methanol prices for North America, Europe and Asia. 13.12. Available from: https:// www.methanex.com/our-business/pricing; 2019. 